\title{
Stress and Academic Performance
}

\author{
Veena $\mathrm{N}^{1 *}$, Shailaja Shastri ${ }^{2}$
}

\section{ABSTRACT}

The study was undertaken to identify the sources of stress among students of high and low academic performance. The questionnaire was administered on 656 pure science and applied science under graduate students from Bangalore city. Academic performance is referred to the end-term results in the previous semester. The tool used for the present study was Stressful Life Events Inventory - Student form (Rao, 1986). The findings of the study showed that majority of the students' perceived education as more stressful. High and low academic performing students as well as pure and applied science course students differed significantly on sources of stress. Implications and suggestions of the study were discussed with teachers and an enrichment program on stress management was employed.

Keywords: Sources of stress, Academic performance, Pure and applied science.

Anything that poses a challenge or a threat to our well-being is stress. Some stresses get us going and they are good for us - without any stress at all many say our lives would be boring and would probably feel pointless. However, when the stresses undermine both our psychological and physical health, they are bad. Students are subjected to different kinds of stressors, such as the pressure of academics with an obligation to succeed, an uncertain future and difficulties of integrating into the system. The students also face social, emotional and physical and family problems which may affect their learning ability and academic performance (Fish \& Nies 1996; Chew-Graham, Rogers, \& Yassin 2003). Too much stress can cause physical and mental health problems, reduce students' self-esteem and may also impinge on students academic performance (Silver \& Glicken 1990; Niemi \& Vainiomaki 1999). In recent years there is a growing appreciation of the stresses involved in education system. (Cited in Sreeramareddy et al., 2007). Sometimes parents, faculty and others tend to idealize their college experience and remember it as that idyllic time when they had few worries or responsibilities.

For students currently attending college, however, the process is often stressful and frustrating. The competition for grades, the need to perform well, relationships, career choices, and many

\footnotetext{
${ }^{1}$ Assistant Professor, P.G. Department of Psychology, Jain University, Bangalore, Karnataka

${ }^{2}$ Professor and Head, P.G. Department of Psychology, Jain University, Bangalore, Karnataka

*Responding Author

(C) 2016 I N Veena, S Shastri; licensee IJIP. This is an Open Access Research distributed under the terms of the Creative Commons Attribution License (http://creativecommons.org/licenses/by/2.0), which permits unrestricted use, distribution, and reproduction in any Medium, provided the original work is properly cited.
} 
other aspects of the college environment cause stress. Before condemning stress outright, we need to understand that stress is only harmful when it is excessive. Much of the stress that we all experience is helpful and stimulating. The challenges of life tend to be stressful and an attempt to avoid stress completely would lead to a rather boring existence. The problem comes when you experience too much stress. Although some stress reactions are part of deeper and more serious emotional problems, many are not, and can be handled with relatively simple counseling and stress-management techniques. The lifetime prevalence of depression, anxiety, and stress among adolescents and young adults around the world is currently estimated to range from $5 \%$ to $70 \%$, with an Indian study reporting no depression among college going adolescents. (Sahoo \& Khess 2010).

Whitman et al., (1985) cites stressful events can be appraised by an individual as "challenging" or "threatening" (Lazarus 1966). When students appraise their education as a challenge, stress can bring them a sense of competence and an increased capacity to learn. When education is seen as a threat, however, stress can elicit feelings of helplessness and a foreboding sense of loss. A critical issue concerning stress among students is its effect on learning. The Yerkes-Dodson law (1908) postulates that individuals under low and high stress learn the least and that those under moderate stress learn the most. A field study and laboratory tests support the notion that excessive stress is harmful to students' performance. Some of the reasons why students perceive stress are time pressure and the need to perform well in the exams (Erkutlu \& Chafra, 2006). Other reasons why stress can occur are the fear of academic failure (Kolko, 1980) too many assignments or the competitions with other students (Fairbrother \& Warn 2003). Mainly the period before the exams is perceived as highly stressful by students (Nandamuri \& Ch, 2011). Stress leads to a detrimental academic performance at the university (Sloboda, 1990). Bennett (2003) reports a similar finding in his study and points out that stress is significantly correlated with poor academic performance. Elias, Ping \& Abdullah, (2011) mentioned that studies show that especially undergraduate students have to handle the possible negative effects of stress concerning their academic achievements. (Cited in Rucker 2012).

As cited in Pfeiffer (2001), there have been many studies (Schafer, 1996; Fisher, 1994; Altmaier, 1983; Greenberg \& Valletutti, 1980), which have reported strong relationship between stress and college students. Some individuals are more sensitive to some stressors than others; so, the person's characteristics and behavior patterns must be looked at to determine their importance and their vulnerability to stress. The experience of stress in humans is universal, but there are also marked individual differences in how stress is experienced. Stress has been known "to be the fuel the body uses to meet the challenges of our fast-paced modern life; for others, it is the aversive by-product of such a life” (Altmaier, 1983). Stress has been associated with major life events, daily life hassles, and changes in life. Stress is created by excessive environmental and internal demands that need constant effort and adjustment. One important factor to consider when researching stress is to explore which sources of stress are beneficial and which sources are detrimental (Ross et al., 1999). Some individuals are more sensitive or prone to some stressors 
than others. Stress is caused by environmental and internal demands that need to be adjusted continuously. These environmental and internal demands will vary from person to person. In 2006 NIMHANS study says 5,857 students committed suicide owing to exam stress. As cited in Petroff (2008) stress had a negative impact on academic success among college students (Andrews \& Wilding, 2004; De Meuse, 1985; Shields, 2001; Struthers et al., 2000). Therefore the present study examined the sources of stress among college students in relation to academic performance, discipline/ course and gender in Bangalore city.

\section{Objective of the Study}

The objectives of present study were as follows-

- To determine the differences between high and low academic performing students sources of stress.

- To determine the sources of stress between pure and applied science course students.

- To determine the differences in the sources of stress between boys and girls.

\section{Operational definition}

Academic performance

The performance of the students in II/III/ IV semester end term examination is considered as academic performance. The students' marks on final examination (based on theory, practicals and internal assessment) were obtained from the educational institution/students marks sheet. The educational institution considers student's marks based on the percentage they have scored in the semester end term examination, where a score of $70 \%$ and above are considered distinction, $50 \%$ and below are considered as pass class. In the present study the same criteria is considered to determine the academic performance grades. The students who have scored $70 \%$ and above are considered as "high academic performers/grades" and 50\% and below are considered to be "low academic performers/grades".

\section{Pure science and applied science}

The students are drawn from two disciplines (pure science course and applied science course). Where pure science students are from undergraduate colleges, studying in II/III/IV semester B.Sc. and have opted Physics, Chemistry, and Mathematics (PCM) combination, affiliated to Bangalore University. Applied science students are from undergraduate colleges, studying in II/III/IV semester B.E and who have opted computer science and information technology, affiliated to Visweshwaraya Technological University.

\section{Hypotheses}

The specific hypotheses formulated were:

1. High and low academic performers do not differ significantly on sources of stress.

2. Pure science and applied science course students do not differ significantly on sources of stress.

3. Boys and girls do not significantly differ on sources of stress. 


\section{METHOD}

\section{Participants}

Participants comprised of 656 college students aged between 19-23 years. Three science undergraduate colleges and five engineering colleges in Bangalore city were considered for the present study. Among these participants, 48\% were from pure science course and 52\% were from applied science course. Boys constituted 47\% and girls 53\%. High academic performers constituted $38 \%$, and low academic performers made up $22 \%$ of the total number of participants.

\section{Tools}

The tool used for the study was stressful life events inventory (Student form), Rao (1986). It was open ended and consisted of 56 discrete events covering seven different areas of stress (Educational, heterosexual, family, financial, health, bereavement, and miscellaneous stress). Dimensions of desirability (positive, neutral and negative) and controllability (within and beyond control) were measured. The distress for each item experienced was rated on a 5 point scale from no distress (0) to severe distress (5). The reliability of the test using Cronbach's alpha was 0.75 . This scale was developed for college students in Indian context.

\section{Socio Demographic Profile}

The data sheet was prepared to elicit information relevant to the study - age, education, gender, class, college and family income - from the respondent.

\section{Procedure}

The researcher obtained the permission from the educational institution to collect the data from the students. Participants were recruited by class as a unit and groups of 35-40 students filled out the questionnaires. Prior to responding to the questionnaires, the consent form was filled and an interactive orientation briefing was organized with students regarding the purpose of the study and the need to answer all the questions frankly.

\section{RESULTS AND DISCUSSION}

The present study investigated the sources of stress among pure and applied science course students (course differences), academic performance (high, average and low) and gender differences. Total fifty six stressors, divided into educational, heterosexual, family, financial, health, bereavement and miscellaneous were assessed in the current study. The responses of the students were analyzed to meet the objectives of the study. Descriptive statistics, Mann-Whitney $\mathrm{U}$, and Kruskal Wallis tests were used to analyze the results. 
Graph 1: Distribution of sources of stress among the respondents.

$\square$ Pure Science $\quad$ Applied Science

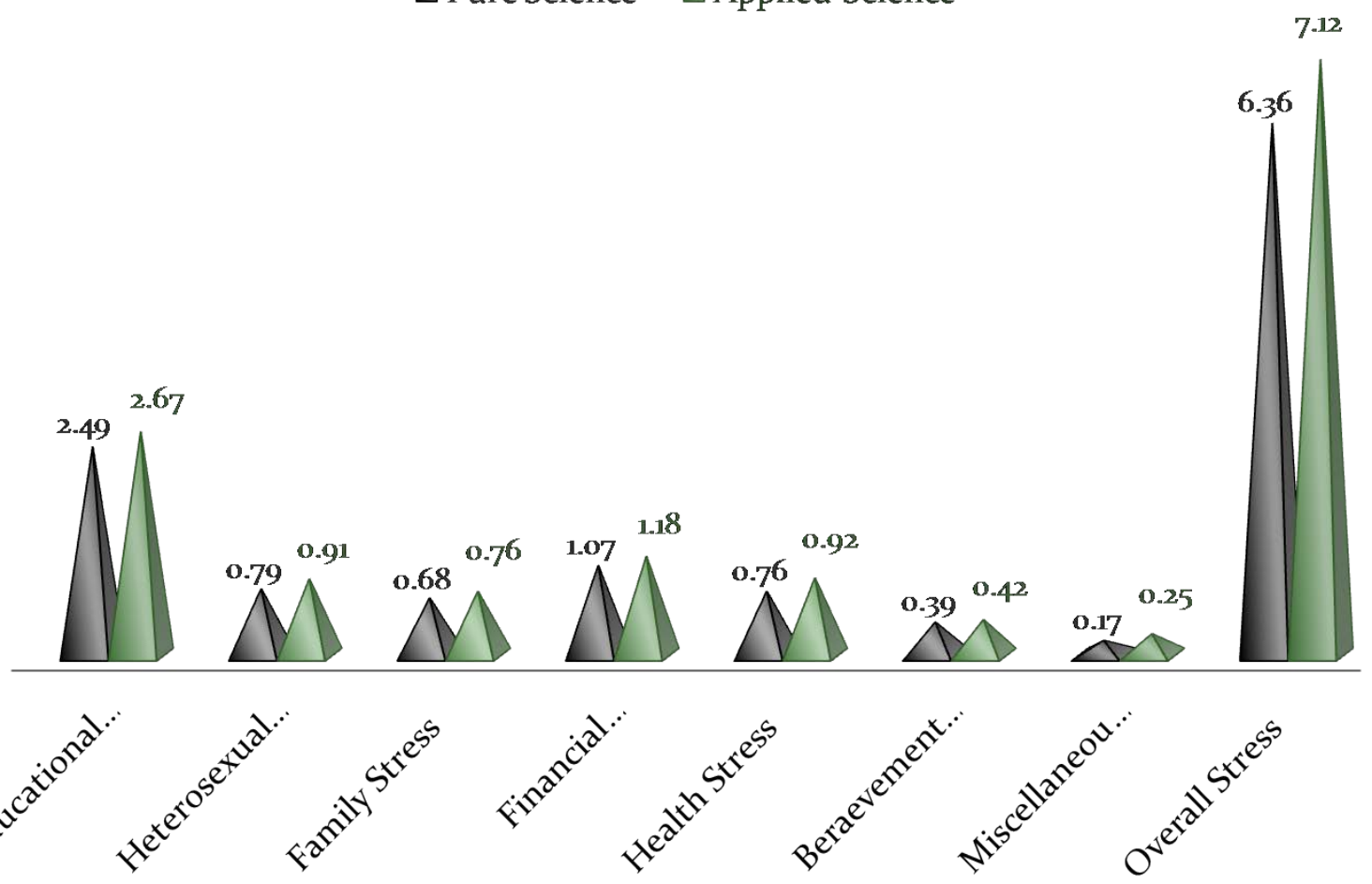

Graph 1 shows the results on different sources of stress among college students. The graph shows that the overall/total and educational stressor was reported as important source of stress. The mean total stress score among applied science discipline is 7.12 and pure science is 6.36 , the overall stress score is 6.75 , therefore it can be said that applied science/engineering students reported experiencing more stress as compared to their counterparts.

In the current study, appearing for examination, failing in examination, change of teacher was reported as important educational /academic stressor. As cited in Elias et al., 2011, Past research has also found sitting for examinations as a source of stress for students (Fan \&Wang, 2001; Li \& Lin, 2003), Brake in friendship, beginning a serious relationship was reported more under heterosexual stressor, changing house, family member leaving the house, mother started working was an important source of stress under family, borrowing the money, loosing important personal belonging was reported more under financial stressor, illness in the close family member, minor physical illness requiring few days off from college was reported as an source of health stressor, death of relative and pet was more under bereavement stressor, under miscellaneous stressor taking alcohol and smoking was reported as a source of stressor.

Zawawi et al., (2012) cites that stress are commonly noted among university students (Towbes \& Cohen, 1996) as they are required to juggle many things at the same time including maintaining good results and adjusting to the new social environment. Towards the end of their study, other issues such as the need to land on good jobs adds to the existing ones, creating a higher level of 
stress (D'Zurilla \& Sheedy, 1991). In general, students reported more stress in educational stress and overall/total stress. As cited in Pfeiffer (2001), there have been many studies (Schafer, 1996; Fisher, 1994; Altmaier, 1983; Greenberg \& Valletutti, 1980), which have reported strong relationship between stress and college students. Abouserie, (1994); Kohn \& Frazer, (1986) report that students experience academic stress predictably, with the greatest sources of academic stress being found in taking and studying for exams and with respect to grade competition and the large amount of content to master in a small amount of time. According to Essandoh, (1995) Psychological distress is reported especially among those who fail to succeed academically. (Cited in Misra et al., 2004). University provides students' tertiary education and psychosocial development (Tao et. al, 2000). Besides pursuing knowledge in university, a student also gets to socialize with different kinds of people and undergo psychological development. Studies show that entering university may bring strain or stress (Gall, Evans, \& Bellerose, 2000). This is because university students face a changing education system, lifestyle, and social environment. University students need to reach certain levels of academic achievement to graduate. The academic achievement is determined by their performance during classroom activities, assignments, presentations and examinations (Ong, Bessie, \& Cheong, 2009). This means that they are evaluated throughout the semester. (Cited in Elias et al., 2011).

\section{Testing of Hypothesis 1}

High and low academic performing students do not significantly differ on sources of stress. To test the significance difference in sources of stress among high and low academic performing students, Kruskal Wallis test was computed. The results are presented in Table 1.

Table 1 Shows Descriptive statistics and Kruskal Wallis test values on different sources of stress between high and low academic performing students.

\begin{tabular}{|c|c|c|c|c|}
\hline \multirow{2}{*}{$\begin{array}{l}\text { Sources of } \\
\text { stress }\end{array}$} & \multicolumn{3}{|c|}{ Academic performers } & \multirow{2}{*}{$P$ value } \\
\hline & High & Low $(\mathrm{N}=141)$ & Chi Value & \\
\hline & & Mean \pm SD & & \\
\hline Educational & $2.33 \pm 1.57$ & \begin{tabular}{|l|l|}
$3.06 \pm 1.37$ \\
\end{tabular} & 30.92 & $<0.000^{* *}$ \\
\hline Heterosexual & $0.84 \pm 1.20$ & $0.98 \pm 1.36$ & 1.085 & 0.581 \\
\hline Family & $0.71 \pm 1.28$ & $0.88 \pm 1.09$ & 7.274 & $0.026^{*}$ \\
\hline Financial & $1.10 \pm 1.29$ & $1.32 \pm 1.31$ & 5.556 & 0.062 \\
\hline Health & $0.89 \pm 1.16$ & $0.93 \pm 1.15$ & 4.356 & 0.113 \\
\hline Bereavement & $0.65 \pm 0.04$ & $0.51 \pm 0.80$ & 1.931 & 0.381 \\
\hline Miscellaneous & $0.16 \pm 0.43$ & $0.33 \pm 0.62$ & 13.022 & $<0.001^{* *}$ \\
\hline Total & $6.40 \pm 5.00$ & $8.03 \pm 4.74$ & 19.031 & $<0.001^{* *}$ \\
\hline
\end{tabular}

$*<.005$ (significant at 0.05 ) $\quad * * \mathrm{p}<.001$ (Significant at 0.01 )

The chi square values clearly indicate that the sources of stress differ significantly between high and low academic performing students. Therefore, the null hypothesis is rejected and alternate 
hypothesis is accepted, which states that there is a significant difference in educational, family, miscellaneous and overall sources of stress between high and low academic performing students. This finding is in line with the past researches (Elias et al., 2011; Choi, Abbott, Arthur \& Hill, 2007; Rafidah, Azizah \& Noraini, 2007). Bennett (2003) reported that stress is significantly correlated with poor academic performance. (Cited in Elias et al., 2011). Studies have found that exams, exam results, and studying for exams were among the highest causes of stress in students (Parisi 2011). Struthers and colleagues, as cited in Petroff (2008) found that stress inversely predicted course grades at the end of the academic year. High stress levels are associated with low academic achievement (Andrews \& Wilding, 2004; Chemers et al., 2001). It is found that stress affects students' academic achievement (Elliot et al., 2005; Choi, Abbott, Arthur \& Hill, 2007; Talib \& Rehman ,2012). Students complained of feeling stressed academically when it comes to facing exams and grade competition and having too much information to study yet insufficient time to master the knowledge (Carveth, Gesse \& Moss, 1996). Kumari \& Gartia (2012) found a positive correlation between stress and academic achievement. Kauts \& Sharma (2009) found in their study that low-stress students performed better than high-stress students, meaning thereby that stress affects the students' performance. Stress is related to academic achievement (Bentley et al., 1980)

\section{Testing of Hypothesis 2}

Pure science and applied science course students do not differ significantly on sources of stress. To explore the significance of differences on sources of stress among pure science and applied science course students Mann Whitney $U$ test was computed and the results are presented in Table 2.

Table 2 Shows Descriptive statistics and Mann Whitney $U$ test on sources of stress among pure and applied science course students.

\begin{tabular}{|l|l|l|l|}
\hline \multirow{2}{*}{ Sources of stress } & \multicolumn{2}{l|}{ Course / Discipline } & \multirow{2}{*}{} \\
\cline { 2 - 3 } & Pure science (N=339) & Applied science (N=317) & \multirow{2}{*}{ P value } \\
\cline { 2 - 3 } & Mean \pm SD & & \\
\hline Educational & $2.49 \pm 1.40$ & $2.67 \pm 1.57$ & 0.257 \\
\hline Heterosexual & $0.79 \pm 1.17$ & $0.91 \pm 1.25$ & 0.132 \\
\hline Family & $0.68 \pm 1.16$ & $0.76 \pm 1.18$ & 0.208 \\
\hline Financial & $1.07 \pm 1.34$ & $1.18 \pm 1.27$ & 0.088 \\
\hline Health & $0.76 \pm 1.12$ & $0.92 \pm 1.19$ & $0.041^{* *}$ \\
\hline Bereavement & $0.39 \pm 0.67$ & $0.42 \pm 0.69$ & 0.573 \\
\hline Miscellaneous & $0.17 \pm 0.49$ & $0.25 \pm 0.61$ & 0.063 \\
\hline Total & $6.36 \pm 4.91$ & $7.12 \pm 4.99$ & $0.018^{* *}$ \\
\hline
\end{tabular}

** $\mathrm{p}<.001$ (Significant)

Table 2 shows the results of two groups who opted for two different courses (Pure and applied.) with regard to sources of stress. The results indicate a statistically significance difference in health and overall stress among pure science and applied science course students. It can be 
inferred that applied science course students experience more stress compared to pure science course students. Hence we reject the null hypothesis and accept the alternate hypothesis which states pure science and applied science course students differ significantly in sources of stress. The findings of this study are in consonance with the study conducted by Singh \& Singh (2008). Womble (2003) in his study cites health-related factors like, nutrition, and amounts of sleep were found to have a great influence on students (Trockel et al, 2000). Stress associated with academic activities has been linked to various negative outcomes such as poor health (Greenberger, 1981; Lesko \& Summerfield, 1989), depression (Aldwin \&Greenberger, 1987), and poor academic performance (Clark \& Rieker, 1986; Linn \& Zeppa, 1984). For example, Lesko and Summerfield (1989) found a significant positive correlation between the incidence of illness and the number of exams and assignments. Similarly, Aldwin \& Greenberger (1987) found that perceived academic stress was related to anxiety and depression in college students. (cited in Kamarudin et al., 2009). But Bataineh (2013) in his study found that there were no significant differences in academic stress among students with different, level of study and specializations.

\section{Testing of Hypothesis 3}

Boys and girls do not significantly differ on sources of stress.

To explore the significance difference between gender and sources of stress, Mann Whitney $\mathrm{U}$ test was computed and the results are presented in Table 3.

Table 3 Descriptive and Mann Whitney $U$ test scores for sources of stress between boys and girls.

\begin{tabular}{|l|l|l|l|}
\hline \multirow{2}{*}{ Sources of stress } & \multicolumn{2}{l|}{ Boys $(\mathrm{N}=305)$} & \multicolumn{2}{l|}{ Girls $(\mathrm{N}=351)$} & p value \\
\cline { 2 - 4 } & Mean $\pm \mathrm{SD}$ & $2.24 \pm 1.36$ & $0.000^{* *}$ \\
\hline Educational & $2.97 \pm 1.54$ & $0.68 \pm 1.03$ & $0.001^{* *}$ \\
\hline Heterosexual & $1.06 \pm 1.37$ & $0.62 \pm 1.10$ & $0.001^{* *}$ \\
\hline Family & $0.84 \pm 1.24$ & $0.94 \pm 1.20$ & $0.000^{* *}$ \\
\hline Financial & $1.35 \pm 1.38$ & $0.79 \pm 1.07$ & 0.402 \\
\hline Health & $0.91 \pm 1.24$ & $0.37 \pm 0.62$ & 0.427 \\
\hline Bereavement & $0.45 \pm 0.75$ & $0.06 \pm 0.24$ & $0.000^{* *}$ \\
\hline Miscellaneous & $0.39 \pm 0.74$ & $5.70 \pm 4.18$ & $0.000^{* *}$ \\
\hline Total & $7.96 \pm 5.49$ & & \\
\hline
\end{tabular}

** $\mathrm{p}<.001$ (Significant)

The results reveal that there is a significant difference in sources of stress among boys and girls. A similar trend of conflicting results has been found with investigation of stress and gender differences. Misra et al., 2004; Roddenberry, 2007; Acharya (2003) reported a significant gender difference in terms of stress. As cited in Petroff (2008) Dusselier and colleagues indicated that females perceived more stress than males and that personal behaviors and relationship conflicts contributed to stress. Sulaiman et al. (2009) found in their study that "female students have different stress compared to the male students. Gentley et al. (2007), results suggest that significant gender differences exist in the experience of stress (as cited in Calaguas 2011). 


\section{CONCLUSION}

The most frequently occurring stressor was related to educational and overall/total domain. The findings of the present study indicate that High and low academic performing students differed significantly on educational, family, miscellaneous and overall sources of stress. Pure and applied science course students differ significantly on health and overall sources of stress. Gender differs on sources of stress. There is a need to address these stressors by education institution as well as by psychologists. As cited in Priya \& Bisen (2012) the amount of stress experienced may be influenced by the individual's ability to effectively cope with stressful events and situations (D'Zurilla \& Sheedy, 1991). If stress is not dealt effectively, feelings of loneliness and nervousness, as well as sleeplessness and excessive worrying may result. It is important that stress intervention programs be designed to address stress of college students. However, in order to design an effective intervention, the stressors specific to college students must be determined (Wright, 1967). Therefore students should be helped with different strategies to improve their ability to cope with a demanding course system and also there is a need to bring a change in the course and also evaluation system in the education scenario. Also coping strategies, that is, dealing with one's own thoughts and feelings, can be facilitated by accessible professional and peer counseling, student support groups, and adequate faculty advising.

\section{IMPLICATIONS}

Stress is necessary to challenge students to learn. Approaches are needed that reduce the negative aspects of stress (distress) which lessen students' learning and performance. The key to reducing distress is providing students with a feeling of control over their education, information about what to expect, and feedback regarding what can be done to improve their performance. Students who do not feel helpless will adopt their own coping strategies. There are several interventions that can be used to cope with stress. There are varieties of coping skills that can be introduced to help students cope with stress. In order for students to eliminate the negative stress that they have, they need to identify the source of the stressor(s). The coping skills that are selected by the student need to be techniques that fit their personal needs. "The widespread prevalence and negative impact of stress on students necessitates the development of effective, efficient programs for stress management” (Altmaier, 1983). (Cited in Pfeiffer, 2001). Brown (1992) offers even more specific suggestions to counselors and university staff for helping students reduce their levels of stress: teach students that stress can be more manageable if it is distributed across the semester, engage students in solving stress by examining which situations have been stressful for them in the past, help students deal with the everyday problems of time management that lead them to procrastinate, and help students develop and maintain the motivation and appropriate behavior to reach long-term goals. (Cited in Dwyer et al., 2001).

\section{LIMITATIONS OF THE STUDY}

This study has some limitations that merit consideration. Namely,

1. The population is limited to pure and applied science course students in Bangalore city. 
2. The participants in this study were from middle to upper-middle class and upper class backgrounds residing in urban environment. Therefore these results can be generalized to similar population only.

3. Only quantitative method is utilized.

\section{REFERENCES:}

Acharya S (2003) "Factors affecting stress among Indian dental students", Journal of Dental Education Oct; 67(10):1140-8.

Retrieved from http://www.ncbi.nlm.nih.gov/pubmed/14587679

Bataineh MZ (2013) "Academic stress among undergraduate students: the case of education faculty at king saud university", International Interdisciplinary Journal of Education, Volume 2, Issue 1. Retrieved from http://www.iijoe.org/v2/IIJOE_05_01_02_2013.pdf

Bentley, Anderson et al., (1980) "Stress Correlates and Academic Achievement",

Retrieved from http://www.eric.ed.gov/ERICWebPortal/search/detailmini.jsp?_nfpb=true\&_\&ERICExtS earch_SearchValue_0=ED208278\&ERICExtSearch_SearchType_0=no\&accno=ED2082 78

Calaguas GM (2011) “College Academic Stress: Differences along Gender Lines”, Journal of Social and Development Sciences Vol. 1, No. 5, pp. 194-201. Retrieved from http://www.ifrnd.org/JSDS/1(5)\%20June\%202011/College_Academic\%20Stress.pdf

Dwyer AL \& Cummings AL (2001) "Stress, Self-Efficacy, Social Support, and Coping Strategies in University Students" Canadian Journal of Counseling, 2001, Vol. 35:3.

Retrieved from http://www.google.co.in/url?sa=t\&rct=j\&q=\&esrc=s\&frm=1\&source=web\&cd=1\&sqi=2 \&ved=0CDMQFjAA\&url=http\%3A\%2F\%2Fcjcrcc.ucalgary.ca\%2Fcjc\%2Findex.php\%2 Frcc\%2Farticle\%2Fdownload\%2F189\%2F430\&ei=1st4Ua2bKoPxrQeogYGYDQ\&usg= AFQjCNF8NalPX9CjC7pEGh9kKPG7boUlfg

Elias H, Ping WS \& Abdullah MC (2011) "Stress and Academic Achievement among Undergraduate Students in Universiti Putra Malaysia”, Procedia - Social and Behavioral Sciences 29 (2011) 646 - 655. Retrieved from http://www.sciencedirect.com/science/article/pii/S1877042811027492 or http://ac.elscdn.com/S1877042811027492/1-s2.0-S1877042811027492-main.pdf?_tid=043414b0b190-11e2-b60000000aab0f01\&acdnat=1367324468_45e6e79a6b7e012e7b14889a52544c6c

Kauts A \& Sharma N (2009) "Effect of yoga on academic performance in relation to stress", Retrieved from http://www.ijoy.org.in/article.asp?issn=09736131; year $=2009$; volume $=2$;issue $=1$; ;page $=39$; epage $=43$; aulast $=$ Kauts

Kamarudin R, Aris A, Ibrahim NA (2009) "Stress and academic performance: a study among pre-science students in uitm negeri sembilan”, Conference on scientific social research. 
Retrieved from http://www.scribd.com/doc/13414586/stress-and-academic-performancea-study-among-prescience-students-in-uitm-negeri-sembilan.

Kumari R \& Gartia R (2012) "Relationship between stress and academic achievement of senior secondary school students”, Asian Journal of Multidimensional Research Vol.1 Issue 3, August 2012, ISSN 2278-4853. Retrieved from http://www.tarj.in/images/download/ajmr/AJMR\%20\%20AUGUST\%202012\%20PAPE RS\%20\%20PDF/AJMR\%20AUGUST\%202012\%20PAPERS\%20PDF/8.13,\%20Radhak anta\%20Gartia.pdf

Misra R \& Castillo LG (2004) “Academic Stress among College Students: Comparison of American and International Students” International Journal of Stress Management Vol. 11, No. 2, 132-148 DOI: 10.1037/1072-5245.11.2.132.Retrieved from http://people.cehd.tamu.edu/ lcastillo/publications/international_stress.pdf.

Parisi M (2011) “The relationship between stress and self-esteem in student athletes versus nonathletes” .Masters dissertation, UMI Number: 1495134, Retrieved from http://gradworks.umi.com/1495134.pdf

Pfeiffer D (2001) “Academic and environmental stress among undergraduate and graduate college students: a literature review”, Research paper, Retrieved from http://www2.uwstout.edu/content/lib/thesis/2001/2001pfeifferd.pdf.

Petroff L L (2008) "Stress, Adult Attachment, and Academic Success among Community College Students” Theses and Dissertations from the College of Education and Human Sciences. Retrieved form http://www.jiaap.org/Default.aspx

Priya \& Bisen V (2012) “An Assessment of Stress among M.B.A. Students: A study of Selected Colleges of G.B.T.U. in Lucknow (India)" International Journal of Business and Management Tomorrow Vol. 2 No. 2. Retrieved from http://www.ijbmt.com/issue/195.pdf.

Rafidah K , Azizah A, Norzaidi MD, Salwani MI, Noraini I (2009) "Stress and academic performance: Empirical evidence from University students”, Academy of Educational leadership journal, Volume 13, Number 1. Retrieved from http://www.ijsre.com/Vol,\%202_1_-Rafidah,\%20et\%20al.pdf.

Roddenberry AC (2007) "Locus of control and self-efficacy: potential mediators of stress, illness, and utilization of health services in college students”, Doctoral thesis. Retrieved from http://etd.fcla.edu/CF/CFE0001831/Roddenberry_Angela_C_200712_PhD.pdf

Rucker J (2012) “The Relationship between Motivation, Perceived Stress and Academic Achievement in Students" Retrieved from http://essay.utwente.nl/62412/1/R\%C3\%BCcker,_J.C._-_s1009699_(verslag) pdf.

Sahoo S \& Khess CR (2010) "Prevalence of depression, anxiety, and stress among young male adults in India: a dimensional and categorical diagnoses-based study”. Retrieved from http://www.ncbi.nlm.nih.gov/pubmed/21135643.

Singh A \& Singh S (2008) "Stress and adjustment among Professional and Non professional students” Industrial psychiatric journal 17(1), 26-27. Retrieved from 
http://www.industrialpsychiatry.org/temp/IndPsychiatryJ171264244463_114724.pdf or http://www.industrialpsychiatry.org/text.asp?2008/17/1/26/63060

Sreeramareddy CT, Shankar PR, Binu VS, Mukhopadhyay C, Ray B \& Menezes RG (2007) "Psychological morbidity, sources of stress and coping strategies among undergraduate medical students of Nepal”. BMC Medical Education 2007, 7:26 doi: 10.1186/14726920-7-26. Retrieved from http://www.biomedcentral.com/1472-6920/7/26\#B1.

Talib N \& Rehman MZU (2012) “Academic performance and perceived stress among university students”, Educational Research and Review Vol. 7(5), pp. 127-132, DOI: 10.5897/ERR10.192 .Retrieved from http://www.academicjournals.org/err/PDF/Pdf\%202012/February/5\%20Feb/Talib\%20an d\%20Zia-ur-Rehman.pdf

Womble, L.P. (2003). "Impact of stress factors on college students' academic performance". Retrieved from http://www.psych.uncc.edu/womble.pdf

Whitman, NA et al (1985) "Students stress: Effects and solutions", Association for the Study of Higher Education. ERIC Clearing house on Higher Education Washington DC. Retrieved from http://www.ericdigests.org/pre-926/stress.htm.

Zawawi D \& Jye KS (2012) "Understanding the stressors and coping strategies among MBA students in Malaysia”, The 2012 International Conference on Business and Management 6 - 7 September 2012, Phuket - Thailand. Retrieved from http://www.caalinteduorg.com/ibsm2012/ejournal/022HRM-DhaliaZ\&KhoSJUnderstanding_The_Stressors_and.pdf

\section{Websites}

http://www.aasra.info/articlesandstatistics.html http://www.counseling.ufl.edu/cwc/stress-and-college-students.aspx. http://www.medicalnewstoday.com/articles/145855.php. 